Int. J. Electrochem. Sci., 16 (2021) Article ID: 210354

International Journal of

ELECTROCHEMICAL

SCIENCE

$\underline{\text { www.electrochemsci.org }}$

\title{
Magnesium Ion-Conducting Biopolymer Electrolytes Based on Carboxymethyl Cellulose Derived from Palm Oil Empty Fruit Bunch Fibre
}

\author{
M.S.A. Rani ${ }^{1,2, *}$, N.S. Isa ${ }^{3}$, M.H. Sainorudin ${ }^{1}$, N.A. Abdullah ${ }^{1,}$ M. Mohammad ${ }^{1 *}$, N. Asim ${ }^{1}$, H. Razali, \\ M.A. Ibrahim ${ }^{l}$ \\ ${ }^{1}$ Solar Energy Research Institute (SERI), Universiti Kebangsaan Malaysia, 43600 Bangi, Selangor, \\ Malaysia \\ ${ }^{2}$ Research Centre for Tropicalisation, National Defence University of Malaysia, Sungai Besi Camp, \\ 57000 Kuala Lumpur, Malaysia \\ ${ }^{3}$ Jabatan Agroteknologi dan Bio-industri, Kolej Komuniti Rembau, 71400 Rembau, Negeri Sembilan, \\ Malaysia \\ *E-mail: iker.asmal55@gmail.com; masita@ukm.edu.my
}

doi: $10.20964 / 2021.03 .08$

Received: 5 October 2020 / Accepted: 29 November 2020 / Published: 31 January 2021

As demands for global lithium supplies have raised questions about the sustainability of the supply of lithium, a potential alternative to lithium batteries has been developed. New biodegradablecarboxymethyl cellulose (CMC) extracted from empty fruit bunches of palm oil is used to produce biopolymer electrolytes (BPE) using magnesium acetate salt. Solution casting has been used to prepare biopolymer electrolytes in various ratios of magnesium acetate. Via Fourier transform infrared characterisation, electrochemical impedance spectroscopy, transference number measurements and linear sweep voltammetry, studies on the structural, electrical and electrochemical behaviour of CMC were conducted. Upon the addition of $20 \mathrm{wt} \%$ of magnesium acetate, the highest ionic conductivity of $1.83 \times 10^{-3} \mathrm{~S} \mathrm{~cm}^{-1}$ at ambient temperature was achieved. The interactions between CMC and magnesium acetate were verified by the Fourier transform infrared results. Electrochemical stability of more than 2 $\mathrm{V}$ was shown by the biosourced polymer electrolytes, whereas the measurement of transference number showed that electrolytic conduction was dominated by ions.

Keywords: carboxymethyl cellulose; biosourced polymer electrolytes; magnesium acetate; electrical studies

\section{FULL TEXT}


(C) 2021 The Authors. Published by ESG (www.electrochemsci.org). This article is an open access article distributed under the terms and conditions of the Creative Commons Attribution license (http://creativecommons.org/licenses/by/4.0/). 